\title{
GOAT KEEPING AND GOAT MILK PRODUCTS IN HUMAN NUTRITION - REVIEW
}

\author{
Tünde Csapóné Riskó ${ }^{1}$, Zsolt Csapó ${ }^{2}$ \\ ${ }^{1}$ University of Debrecen, Faculty of Economics and Business, Institute of World Economy and International \\ Relations, H-4032 Debrecen, Böszörményi út 138 \\ E-mail: risko.tunde@econ.unideb.hu \\ ${ }^{2}$ University of Debrecen, Faculty of Economics and Business, Institute of Applied Economics, \\ H-4032 Debrecen, Böszörményi út 138. \\ E-mail: csapo.zsolt@econ.unideb.hu
}

\begin{abstract}
The aim of this paper is to review the status quo and future perspective of goat keeping and goat milk products, particularly emphasising the role of goat milk products in human nutrition. Across the globe, goats can be kept almost anywhere, even in poor surroundings. Considering the deteriorating geographical conditions due e.g. to global warming, the importance of goat and goat products will probably further increase. Goats can play an important role in the nutrition of the continuously increasing human population. The wool, meat and milk of goats are all valuable products. Goats are able to provide high quality products under diverse climate conditions and in extreme environments. Globally, more people drink milk from goats than from any other animal. Due to the components and profile of goat milk, it can be processed and a wide range of high quality and healthy value added products can be produced from it. Goat milk plays a decisive role in feeding starving and malnourished people in developing countries. In developed countries, a significant segment of many populations suffers from gastro-intestinal disorders and cow milk allergy. Goat milk plays an important role in the treatment of certain health problems. Moreover, due to its favourable effects on human health, goat milk has found a niche for itself in the trend towards healthy nutrition in developed countries, where connoisseur consumers are ensuring goat milk products a growing market share. In these countries, goat milk products, e. g. cheeses are also recognised as gastronomic and festive products.
\end{abstract}

Keywords: Goat, goat milk products, human health

(JEL Classification: Q13)

\section{Climate change, global warming and the (dairy) goat sector}

The environment is rapidly changing due to climate change. Countries in the temperate zone are also affected by changes in global warming. These changes are associated with extreme high temperatures and seasonal changes. The number of days with a temperature humidity index above a specific comfort threshold has remarkably increased in recent years in European countries located in the temperate zone. The rate of global warming is expected to continue in the future. Agricultural production (plant production and animal husbandry), and thus global food security, is already affected by climate change and will continue to be influenced by global warming. Thus, these changes will continue to affect the dairy industry, directly and indirectly. Among domestic ruminants, goats are the most adapted species to heat stress in terms of production, reproduction and resistance to diseases. Climatic change would negatively affect the dairy industry and the importance of goats to the dairy industry would increase (SILANIKOVE and DARCAN, 2015).

The economic importance of goat production has increased worldwide during the last few decades, especially in countries that are often exposed to harsh environments. Goats have many advantages that enable them to maintain their production under extreme climate and geographic conditions. Among domestic ruminants, goats have the highest capacity to effectively convert feed into meat and milk. Furthermore, goats emit less methane than other domestic ruminants. Based on these advantages, DARCAN and SILANIKOVE (2018) came to the conclusion that goat breeding would play an important role in mitigating and adapting to climate change in harsh environments.

STEINFELD et al. (2006) underline that the total amount of greenhouse gas emissions is closely related to animal husbandry. The use of goats with better efficiency to convert feed resources into products may become an important strategy for alleviating greenhouse gas emissions originating from livestock (STEINFELD et al., 2006).

DARCAN and SILANIKOVE (2018) emphasizes the importance of benefiting from the genetic potential of local goats, which are the most resistant breeds to diseases, drought and local climate conditions. These physiological factors relate to the goat's ability to maintain productivity under severe 
conditions. Low metabolic heat production, tolerance to lack of water, morphologic and anatomic structure enabling efficient utilization of poor quality feed, reproductive capacity, sweat gland capacity, as well as resistance to diseases and parasites have been identified by DARCAN and SILANIKOVE (2018) as the advantages of goats to future adaptation to climate change.

PEACOCK and SHERMAN (2010) highlights that a number of significant global trends are likely to impact goat production systems negatively or positively in the future. These trends include global warming, the rising costs of nonrenewable energy, the rising cost of grain, human population growth, changes in human diet, livestock population growth, and degradation of the environment.

\section{Goat keeping and goat milk production}

Except for in the Antarctic, goats providing milk for human consumption can be found all over the world (HAENLEIN, 2017). The number of goats has reached 1 billion. The population has increased by more than $50 \%$ during the last 40 years, especially in Africa and Asia (HAENLEIN, 2001). The number of goats is stagnant in the Americas and slightly decreasing in Europe, but increasing in the Mediterranean countries, which reflects dairy goat increases against dual purpose, meat, brush and fibre goats (HAENLEIN, 2017). There are almost 500 goat breeds in the world, but only a half dozen are raised for their milk. Currently, some 600-700 million dairy goats are being kept (KRIS, 2008). More than $95 \%$ of the goat population can be found in developing countries. Worldwide trends of the evolution of the goat population and their products between 1969 and 2010 show a continuous and rapid increase, especially in developing countries THORNTON (2010).

About 95 percent of the world's goat population is found in Asia, Africa and Latin America. Asia's share is the largest, with approximately 60 percent of the total. Most dairy goat is raisesd in the Mediterranean region, South Asia and parts of Latin America and Africa. The countries with the largest dairy goat populations are Bangladesh, India and Mali. The Near East region has the highest sheep and goat milk production per inhabitant. Major goat milk producers are India, Bangladesh and Pakistan. The average milk yields of goats vary significantly among major milk producing countries. In Bangladesh, the average goat milk yield is about 80 $\mathrm{kg} / \mathrm{year}$, while in India and Pakistan, it is higher than $140 \mathrm{~kg} /$ year. Goat milk contributes significantly to the total milk production in sub-Saharan Africa (13\%) and parts of South, East and Southeast Asia (excluding China) (FAO, 218).

ZENEBE et al. (2014) emphasise that goats are an important component of the livestock industry, as they can adapt to harsh climates, which make them suitable for landless and marginal farmers. SILANIKOVE (1994 and 2000) also mentions their ability to provide high quality food under diverse climatic conditions. Their resilience in extreme and capricious environments makes goats so popular. The contribution of goats in supplying milk and milk products is high and plays an important role in rural economies and health. GARCÍA et al. (2014) also mentions that goat production constitutes an important part of the national economies of many countries, especially in the Mediterranean region and the Middle East. In Europe, such activity has particular importance in France, Italy, Spain and Greece. Furthermore, goat milk is an excellent food source.

MORAND-FEHR (2003) also reports that the number of goats has been increasing over the previous 20 years. Their number has increased by almost $50 \%$ worldwide, while the number of cattle has only increased by $9 \%$, and the number of sheep decreased by $4 \%$ (MORAND-FEHR and BOYAZOGLY, 1999; DEVENDRA, 2001). Therefore, among these ruminants, goats seem to be one of the major livestock species rising in number (ANAETO et al., 2010).

Over the previous 20 years, a new and growing interest has occurred all over the world towards goat milk and goat milk products (DUBEUF, 2010). The goat milk production of the world showed an increase of 62\% from 1993 - 2013 from 11 to 18 million tons (HAENLEIN, 2017). As Figure 1 shows, global goat milk production increased between 2000 - 2013. Regarding continents, most goat milk is produced in Asia (10.65 million tons), followed by Africa (4.65 million tons), Europe (2.53 million tons) and the Americas ( 0.59 million tons). After cows, the animal that is most widely used to provide milk for human consumption is the goat (HARREN, 1994).

Table 1 shows the top 10 global goat milk producers in 2017. The country producing the most goat milk is India (5 million tons) followed by Bangladesh ( 2.6 million tons) and Sudan (1.5 million tons). It has to be added that actual goat milk production is likely to be much higher than what is seen in official statistics, because of the large amounts of unreported home consumption, especially in developing countries (HAENLEIN, 2004 in YANGILAR, 2013).

Figure 1: Goat milk production in the world, 2000-2013, Million tons

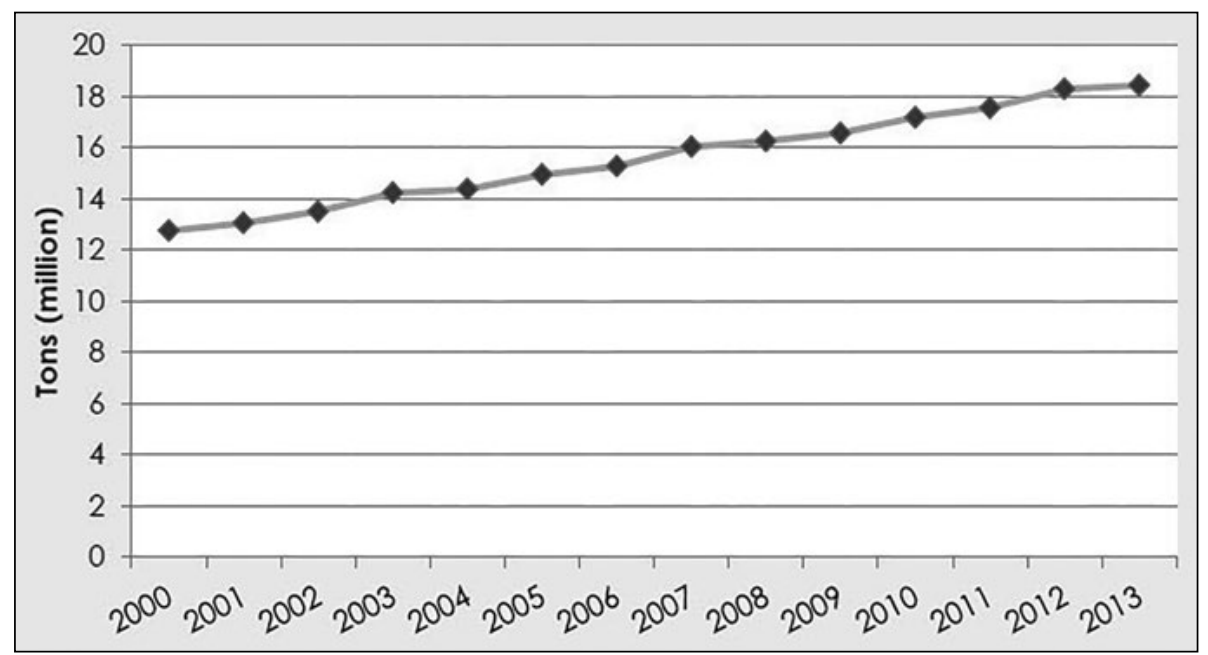

Source: Department of Agriculture, Forestry and Fisheries, Republic of South Africa, 2016 
Table 1: Top 10 goat milk producing countries of the world in 2017

\begin{tabular}{|l|l|l|}
\hline Rank) & Country & Production (tons) \\
\hline 1 & India & 5.000 .000 \\
\hline 2 & Bangladesh & 2.616 .000 \\
\hline 3 & Sudan & 1.532 .000 \\
\hline 4 & Pakistan & 801.000 \\
\hline 5 & Mali & 720.000 \\
\hline 6 & France & 580.694 \\
\hline 7 & Spain & 471.999 \\
\hline 8 & Turkey & 415.743 \\
\hline 9 & Somalia & 400.000 \\
\hline 10 & Greece & 340.000 \\
\hline
\end{tabular}

Source: worldatlas, 2017

As MOWLEM (2005) and SEREGI and KOVÁCS (2016) conclude, in developed countries with sophisticated food industries, goat products fit into two niches, that of health foods and that of products for use by gourmet cooks. In the developing world, goats can mean the difference between malnourishment and a healthy sustaining diet. PIRISI et al. (2007) also mention that goat milk and its products are fashionable in some parts of the world, where medical needs and connoisseur interests drive these markets. Nevertheless, consumer interest in the great variety of goat milk products, especially those of 'organic' origin or of traditional labels, has seen considerable growth in recent years (PANDYA and GHODKE, 2007).

\subsection{Goat keeping and goat milk production in developing countries}

The world's human population size increased from 5.5 to 7.2 billion from 1993 to 2013. Goats have had a superior growth rate in numbers compared to other milk producing domestic animals, especially in developing countries with large human population increases and high rates of under nutrition and malnutrition. The large goat number increases in Asia and Africa were an attempt to keep pace with the need to feed more people, and more people are exposed to goat milk worldwide than to any other milk (HAENLEIN, 2017).

DEVENDRA and MCLEROY (1982) point out that, due to the rapidly increasing human population, the demand for milk and milk products is on the rise in tropical developing countries. DEVENDRA (1999) reports that the contribution of small ruminants in general and goats in particular in meeting this demand will be very high. Goats are important milk producers in several parts of the tropics and contribute significantly to human nutrition in many developing countries.

The current world population of 7.6 billion is expected to reach 8.6 billion in 2030, 9.8 billion in 2050 and 11.2 billion in 2100, according to a United Nations report launched on 21 June 2017. With roughly 83 million people being added to the world's population every year, the upward trend in population size is expected to continue, even assuming that fertility levels will continue to decline. From 2017 to 2050, it is expected that half of the world's population growth will be concentrated in just nine countries: India, Nigeria, the Democratic Republic of the Congo,
Pakistan, Ethiopia, the United Republic of Tanzania, the United States of America, Uganda and Indonesia. The concentration of global population growth in the poorest countries presents a considerable challenge to governments in implementing the 2030 Agenda for Sustainable Development (UN, 2017).

As Table 1 also indicates, more than 95\% of the goat population can be found in developing countries (PEACOCK, 1996). Goats are the main suppliers of meat and dairy products for rural people in these countries (KRIS, 2008). In developing countries, goats are often kept in marginal environments under unfavourable climatic and scarce grazing conditions. Goats are the dairy animals of the poor because of the lower capital investment and production costs required, and the animals' rapid generation turnover (earlier milk production in comparison with other dairy animals), short pregnancies and milk supply in quantities that are suitable for immediate household use (DEVENDRA, 1999). Similarly, ANAETO et al. (2010) point out that goats not only provide families with protein, but can also be a source of livelihood generating income for the family. Goats are the major source of milk and meat for many subsistence farmers in tropical regions. Goats are common in arid and semi-arid areas and are generally kept in small flocks (2 to 10 animals). Goat milk is widely produced in West Africa, but also in the Caribbean and Central Africa, usually for household consumption, although it is sometimes traded within the community (FAO, 2018). DUBEUF et al. (2004) also emphasise that the greater portion of goat milk is still not widely traded, but is consumed locally. Although most dairy goats are kept in developing countries, breeding programmes are concentrated in Europe and North America. Genetic selection of dairy goats has resulted in considerable increases in yields and longer lactation periods. The specialized dairy goat breeds used in developed countries have higher genetic potential for milk production than breeds kept in the developing world. In recent decades, specialized breeds have been exported to many developing countries and crossed with local breeds, in order to improve milk production (FAO, 2018).

DUBEUF (2010) writes in more detail on the situation of dairy goats and goat milk in developed and intermediate countries. He also refers to the fact that most of the milk is autoconsumed or sold locally through the informal sector. Thus, it is difficult to determine the amount of goat milk produced and auto-consumed or sold in the local market because of the lack of global statistical data on goat milk and generally very little national data. Cultural habits and tastes regarding goat milk differ from country to country and cultural groups to cultural groups within countries. For instance, Middle Eastern and Central Asian peoples have old traditions of consuming goat milk, while such traditions are rather non-prevalent in Far Eastern or Western African countries, where some populations have taboos for this type of milk. At the opposite extreme, the statistics confirm the importance of goat milk in Central and Southern Eastern Africa. It contributes significantly to the milk supply of the population in such poor countries as Mali, Niger, Kenya, Tanzania or Sudan, although the data are probably not precise due to the informal very traditional conditions. Several projects in East Africa have shown that dairy goats can contribute significantly and improve the incomes of village 
people (PEACOCK, 2008). The dairy goat sector in India is rather marginal, despite India being the most important goat producer and the main goat milk producer. Goat milk is not only $3.2 \%$ of the national milk production, but most of it is auto-consumed by the rural population. Goat milk is not well priced, its products do not have a lucrative market and it is generally produced by lower castes. South America, with its Hispanic tradition for consuming goat milk cheeses, has several regional collecting points for goat milk in Brazil, Mexico, Argentina and Chile, even if the economic importance of the sector is still very low (DUBEUF, 2010).

Regarding developing countries, IDACHABA (2000) and ANAETO et al. (2010) summarise the advantages of goat keeping:

- They refer to goats as 'walking factories' producing food for man as they graze on pastures and eat farm by-products, thus reducing the costs of weeding and feeding. Goats can utilise feed which is difficult to consume for cattle.

- Goat keeping provides a source of income for the family.

- Goat products greatly contributes to the protein intake of the family.

- Goats have short generation interval. They are early maturing and can reach puberty as early as 4 months.

- There are no religious restrictions regarding the keeping of goats and consuming their products; rather, they are favoured by religious festivals and other social engagements.

\subsection{Goat keeping and goat milk production in Europe}

Figure 2 shows the livestock population in the EU-28 from 2010 to 2016. Of the reported animals, we focus here on the number of goats. The largest relative decrease in the livestock population was reported for goats for this period, with a fall of $3.7 \%$. However, in 2016, the population of goats increased by $2.0 \%$ compared to the year before (EUROSTAT, 2017).

Figure 2: Livestock population, EU-28, 2010-2016 (Million heads) $(2010=100 \%)$

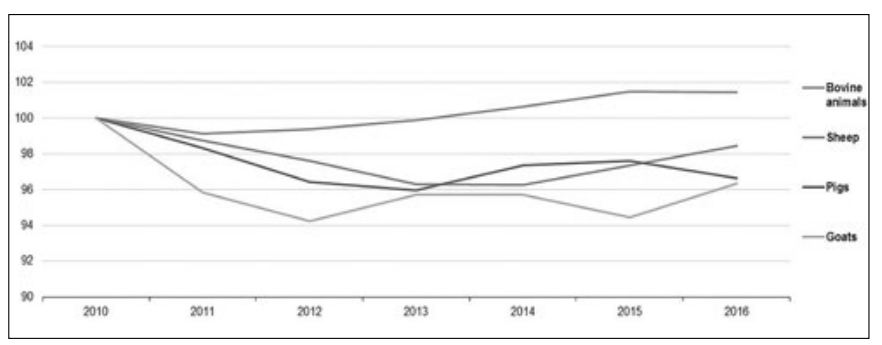

Source: Eurostat, 2017

As KUKOVICS (2008c) reports, in Europe, most of the goat population were held in the Mediterranean countries (Greece, Spain, Italy, Portugal and France), in the Netherlands and Romania. Regarding dairy goats, $40 \%$ of the European dairy goat population was held in France, the Netherlands and Spain. These three countries were the biggest goat milk producers within the EU.
In 2016, Greece (3.89 million head) held the largest population of goats in the EU-28, as shown in Table 2. In 2016 Greece, Spain, Romania, France and Italy had the largest goat populations (EUROSTAT, 2017).

Table 2: Goat population in EU-28 countries in 2016

\begin{tabular}{|l|l|}
\hline Country & Million head \\
\hline EU-28 (1) & 12.78 \\
\hline Belgium & no data \\
\hline Bulgaria & 0.24 \\
\hline Czech Republic & no data \\
\hline Denmark & no data \\
\hline Germany & 0.14 \\
\hline Estonia & no data \\
\hline Ireland & no data \\
\hline Greece & 3.89 \\
\hline Spain & 3.09 \\
\hline France & 1.20 \\
\hline Croatia & 0.08 \\
\hline Italy & 1.03 \\
\hline Cyprus & no data \\
\hline Latvia & 0.01 \\
\hline Lithuania & 0.01 \\
\hline Luxembourg & no data \\
\hline Hungary & 0.08 \\
\hline Malta & 0.00 \\
\hline Netherlands & 0.50 \\
\hline Austria & 0.08 \\
\hline Poland & no data \\
\hline Portugal & 0.35 \\
\hline Romania & 1.48 \\
\hline Slovenia & no data \\
\hline Slovakia & 0.04 \\
\hline Finland & no data \\
\hline Sweden & no data \\
\hline United Kingdom & 0.10 \\
\hline & $0 S T$ Ta \\
\hline
\end{tabular}

(1) EU-28 EUROSTAT Estimates Source: Eurostat, 2017

In some European countries (Greece, Albania, Bulgaria, Bosnia and Herzegovina, Croatia and Slovenia), the contribution of goats and sheep to dairy production is remarkable, around $40 \%$, and in some of them (e.g. Greece) it even exceeds that of cows (FAO, 2018 and HAENLEIN, 2001 in SILANIKOVE and DARCAN, 2015). The main reason for this situation relates to the ability of goats to uniquely and effectively exploit the vast scrublands and woodlands characterizing these countries (SILANIKOVE, 2000 in SILANIKOVE and DARCAN, 2015).

DUBEUF (2010) writes precisely on the situation of goat milk products in Europe. He points out that Europe owns only $2.5 \%$ of the world goat population, but its share in the world's goat milk production is $18 \%$. It is the only continent where goat milk has such an economic importance and organisation; however, the situation varies between countries. Most of the production is marketed, although an informal sector still remains active in southern European countries. Goat milk products are nearly exclusively cheeses. Recent sales of UHT 
goat milk have increased due to its dietetic quality. Globally, the goat sector is clearly positioned on quality dairy products for rather high income consumers. He adds that goat milk consumption has a long tradition in Southern Europe. Despite this and producing more than $80 \%$ of the total European yield, goat milk and cheese is often less appreciated than ewe milk and cheese and is in direct competition with sheep products in Spain, Greece and Portugal.

MOWLEM (2005) reviews the dairy goat sector of the UK in his study. He states that goats have always been part of the fringes of agriculture in the UK. Goats were probably introduced by the Romans 2,000 years ago. During the Middle Ages, goats were seen as undesirable probably because they did not conform to the new agricultural revolution. Since those times and, in fact, as recently as the previous 30 years, there has been an increase in interest in goat production which - as may be expected - has followed increased market possibilities for the products. He also adds that in the UK, goats had a 'very bad press' for many years and, as a result, considerable prejudice against all goat products existed. He assumes that goat milk would be described by almost everyone who was not a goat enthusiast as 'strong, smelly, salty or sweet'. With such a reputation, it was almost impossible to persuade anyone to taste goat milk, even if offered to them at no cost.

\subsection{Goat keeping and goat milk production in Hungary}

Goat breeding in Hungary has a history of prohibitions and regulations. During the Middle Ages, goats were prohibited on certain territories. At the end of the XVIIIth century, a law was made that only poor people and people with health problems were allowed to keep goats. Thus, goats became the cows of poor people. The goat population was 270.000 at the end of the XVIIth century and 17.317 in 1885 (MUCSI, 2004 in KOCSISNÉ GRÁF, 2011).

Until the end of the 1990s, goat breeding in Hungary was relatively unimportant. However, new demand for so-called alternative products meeting the requirements of healthy nutritional programmes began to appear in the country, as well. Initially, this new demand was met with imported products, since the national goat population and goat dairy products could not compete with imported products (MARTICSEK et al., 1999). Due to many efforts, today, local goat milk and manufactured goat milk products can meet any and all market requirements (SZIGETI, 2004).

2000 - 2017. The number of individuals and companies keeping goats as a livelihood generated income or business reasons is probably a few hundred in Hungary. The number of farmers keeping some goats as a hobby or providing the family with goat milk is probably a few thousand (KUKOVICS, 2007a). There are around 3-5.000 goat keepers in Hungary (the exact number is not known) and less than $80 \%$ keeps less than 10 goats. The breeds mainly belongs to Hungarian breeds, but $10 \%$ stem from imported breeds, such as Saanen, Alpine, Boer or Anglo-Nubian (KUKOVICS, 2008a). Many poor people keep goats in Hungary, in mainly underprivileged regions (KUKOVICS, 2007b). The production level (and number of animals), as well as keeping conditions are lagging behind the data for France, Spain, Italy, Greece and the Netherlands (KUKOVICS, 2008b). Production level of the sector is weak and has been struggling with several problems for many years. The number of goat breeders and goats continuously fluctuates and the data are patchy. With the growing importance of healthy nutrition and lifestyle, growing demand is expected for goat milk and goat milk products, that could contribute to the development of the goat sector (KOCSISNÉ GRÁF, 2011).

Although goat breeding has seemed to be more organized since 2009, the number of goats in nucleus herds was still much lower in 2013 than before 2008. Most goats still do not belong to any specific breed, and most herds and animals are not registered or individually identified. The Hungarian Sheep and Goat Dairying Public Utility Association has assisted milk production and processing, and product marketing, but organized sales of meat products (slaughter kids and adult goats) were still lacking in 2013. The quality of breeding work should be improved and product marketing has to be developed to ensure a brighter future for goat farmers in Hungary (KUKOVICS and BARANYAI, 2016).

The main product of the goat sector is milk. The estimated goat milk production is around 3-5 million litre per year, but only 0.6 million litres are manufactured by milk factories. The main income of milk producing farmers comes from milk and manufactured goat milk products. It is common in the sector that goat breeders sell the produced goat milk and self-made dairy goat products directly (HUNGARIAN CHAMBER OF AGRICULTURE, 2017). Figure 4 shows the goat milk production in Hungary between 2000 - 2016.

Figure 3: Goat population in Hungary between 2000-2017 (thousand heads)

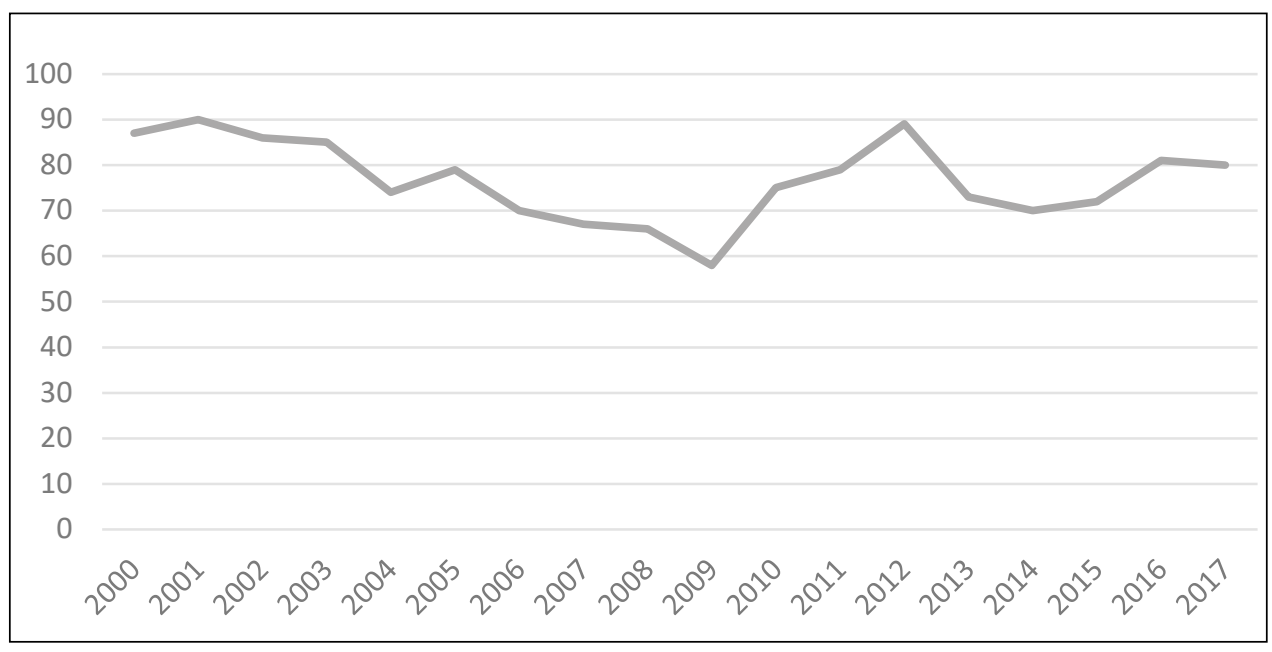

Source: KSH, 2018a 
Goat milk is processed by only a few small or larger dairy plants in Hungary. Processing plants have to overcome several difficulties, such as the dispersion of breeding farms, and competition with products imported from other EU and neighbouring countries (Slovakia and Romania), which are readily accepted by Hungarian consumers (SEREGI and KOVÁCS, 2016). be considered as mass products; rather, its niche should be strengthened. When promoting them, their tastiness, healthiness and traditional nature should be emphasised, but their reliable Hungarian origin, as well as their quality should also be pointed out (CSAPÓ and CSAPÓNÉ, 2019).

\subsection{Goat keeping and goat milk production in developed countries of other continents}

Figure 4: Goat milk production in Hungary between 2000-2016 (million litres)

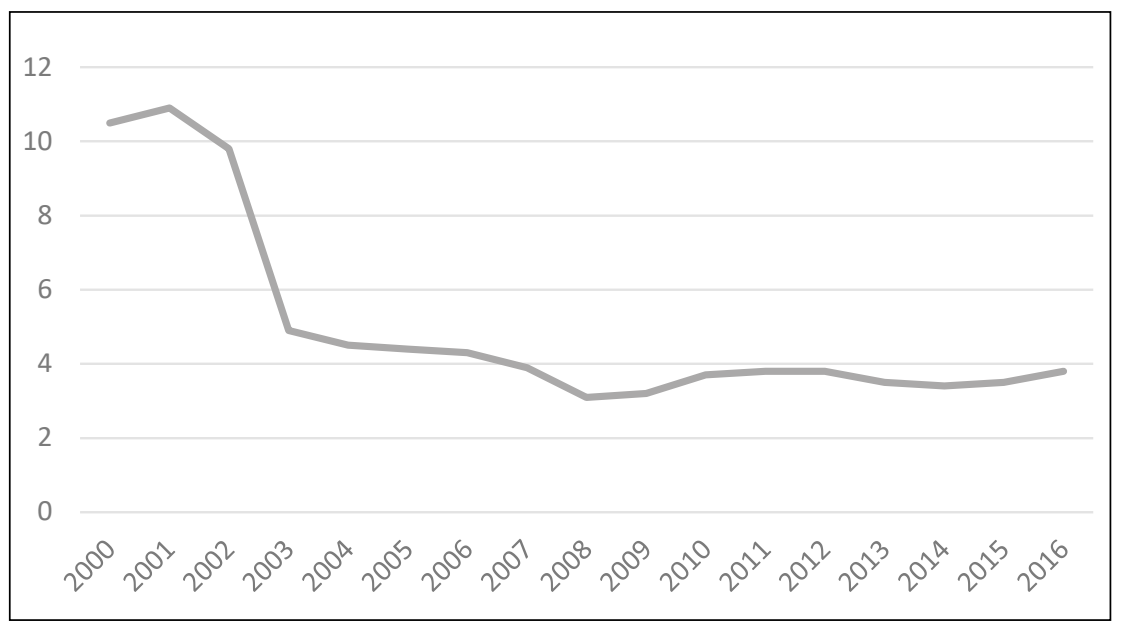

Source: KSH, 2018b

DUBEUF (2010) gives a rather detailed outlook of the goat milk sector in the developed countries of other continents. In the USA and Canada, goat milk is clearly a niche product. Between 1960 - 1970, goat milk was considered only as a minor substitute of cow milk. An enthusiastic interest for goat cheeses started in the early 1980s, when goat cheese became a gourmet item. In other developed countries, the goat sector is small, although it could be well organised. In New Zealand, the NZ dairy goat co-operative has 85 breeders with an average herd size of 250 . Most of the milk is used as milk for kids or UHT milk and exported to countries such as Taiwan. Israel also has a well organised intensive dairy goat sector with a significant part of the production exported as frozen curd to the USA (BERINSTAIN-BAILLY,

FENYVESSY (2009) reports that goat milk and its role in human nutrition came into fashion in the Hungarian press only in recent years. The articles emphasise the role of goat milk and goat dairy products in preserving health, although the statements are sometimes contradictory.

Goat cheeses made from domestically produced milk are available in the Hungarian market, together with more expensive imported (e.g. French, Greek) goat cheeses. Many of the Hungarian cheeses are of excellent quality, having a clear taste and proper texture, with adequate shelf-life and a "goat flavour" that is not as intense as that of imported cheeses (SEREGI and KOVÁCS, 2016).

SZIGETI (2004) and SZIGETI et al. (2005) report on the results of an empirical research study carried out in Hungary. Only a small ratio of respondents reported only very rarely buying and consuming goat dairy products. The most often purchased product was cheese. The main reason for refusing goat dairy products were: they did not like the taste of goat dairy products, they did not even know these products, these products are not easy to find and buy. The main reasons for buying these products are: healthiness, taste and quality. The respondents were concerned that goat dairy products were expensive. The research revealed that respondents were not familiar with the available brands and nutritional benefits of goat dairy products. Another empirical research study (SZIGETI el al., 2014) revealed that the opinion of Hungarian respondents had not changed much since the time of the previous studies. Goat dairy products are still rarely consumed. The most preferred products are cheeses, followed by cottage cheese. Goat dairy products should not

\section{7 in DUBEUF, 2010).}

Goat cheese in the US has gained popularity among ethnic groups, gourmet and health food lovers and goat farmers (RIBEIRO and RIBEIRO, 2010; PARK, 2011).

\section{The nutritional and medicinal importance of goat milk}

One of the most decisive factors in the growth in the consumption of goat milk and derived products is their perceived beneficial effects on human health which, moreover, are fully recognised by the scientific community (GARCÍA et al, 2014).

The use of goat milk as an excellent food source is undeniable. It has beneficial effects for health maintenance, physiological functions, in the nutrition of children and elderly people (BILLION, 2003; ALBENZO et al., 2006; DOMONKOS and GEINER, 2009; YANGILAR, 2013).

BARNA (2009) emphasises that the folic acid content of goat milk is relatively low (the folic acid content is 5 times higher in human milk and 6 times higher in cow milk, while the folic acid content of sheep milk is the same as human milk). In mixed diets, goat milk can be applied but the folic acid need of the body has to be ensured by other foods (e.g., oat flakes, green peas, dry beans, almond, orange, banana). Due to its nutritional value, goat milk and manufactured goat milk products are recommended in the healthy diets of children. When devising a healthy children's menu, balance, diversity and self-restraint have to be considered.

Goat milk differs from cow or human milk in having better digestibility, alkalinity, buffering capacity and certain therapeutic values in human nutrition and medicine (HAENLEIN and CACCESE, 1984; PARK and CHUKWU, 
1989; PARK, 1994; LIMA et al., 2018).

The unique characteristics of goat milk have been fairly well surveyed regarding nutritional value and health effects. The superior digestibility of goat milk, the proper composition of fatty acids, protein and its content of bioactive compounds seem to give properties suitable for treating or preventing certain medical conditions. Goat milk has beneficial effects on malabsorption disorders and inflammatory bowel diseases. Goat milk contains higher amounts of calcium, magnesium and phosphorous than cow and human milk. Medium chain triglycerides and proteins occur more in goat milk, and have been recognised as unique lipids and proteins with unique health benefits. The soft curd of goat milk may be an advantage for adult humans suffering from gastrointestinal disturbances and ulcers. Goat milk is important for prevention of cardiovascular disease, cancer, allergy and microorganism and used for stimulation of immunity. Goat milk is recommended for infants, old and convalescent people (HAENLEIN, 2004; ZENEBE et al., 2014).

Comparing the biological value of goat, sheep and cow milk protein, FENYVESSY (2009) stated that the protein of goat milk was the most valuable, followed by the protein of sheep and cow milk. The ratio of essential amino acids was $46.7 \%$ in cow milk, $48.0 \%$ in sheep milk and $52.5 \%$ in goat milk (AGNITHORI et al., 1993 and FENYVESSY et al, 2001 in FENYVESSY 2009).

Goat milk has predominantly smaller fat globules compared to cow milk and is easier to digest (FEVRIER et al., 1993; JANDAL, 1996; LÓPEZ et al., 2003; RAMOS et al., 2005; OLALLA et al., 2009; YANGILAR, 2013). Thus, goat milk is a valuable alternative for babies, adults and nursing mothers, also (BALDO, 1984; HOST et al., 1988).

JENNESS (1980) reports that one of the most important contributions of goat milk to human nutrition is the calcium and phosphate that it supplies. Human milk contains much less of these minerals. Goat milk provides a great excess of $\mathrm{Ca}$ and $\mathrm{P}$, in relation to energy to human infants. Both calcium and phosphorus of goat milk are absorbed by the human infant. Building on the comparative laboratory test results of O'CONNOR (1994,) where the composition of the minerals and vitamins in human and goat milk was investigated, ANAETO et al., (2010) states that the mineral content of goat milk is higher, and these properties help to prevent iron deficiency anaemia and bone demineralisation. Regarding vitamins, in comparison with cow milk, goat milk has lower amounts of vitamin E, folic acid, and vitamin B12, which can result in "goat milk anaemia" if additional sources in these vitamins are not present in the diet LIMA et al. (2018).

Goat milk has been recommended as a substitute for patients allergic to cow milk (TAITZ and ARMITAGE, 1984; PARK, 1994; GUO et al., 2004; YANGILAR, 2013). 40-100\% of patients allergic to cow milk proteins tolerate goat milk (ZEMAN, 1982; PARK, 1994). The uniqueness of goat milk, yoghurt and cheese in human nutrition has several aspects: goat milk can be used for the treatment of direct or indirect cow milk allergy (GREZESIAK, 1989 in ANAETO et al., 2010). YANGILAR (2013) and LIMA et al. (2018) also emphasises that the goat's milk nutritional properties and lower allergenicity in comparison to cow milk, especially in non-sensitised children, has led to an increased interest in goat milk as a functional food, and now it forms part of the current trend to healthy eating in developed countries. However, POLGÁR (2009) and DOMONKOS and GEINER (2009) indicate that the research results on this issue are rather contradictory.

Goat milk contains much taurine $(6.62 \mathrm{mg} / 100 \mathrm{ml}$ in general, but the milk of Mediterranean goat contains even more, 6.90-11.37 $\mathrm{mg} / 100 \mathrm{ml}$, which is 10 times more than the taurine content of cow milk). It can be assumed that with goat milk, health problems with taurine deficiency can be influenced favourably (PASQUALONE, 2000 IN BARNA, 2009). There are reports that goat milk contributed to the treatment of diabetics (ANAETO et al., 2010).

The higher proportion of medium-chain fatty acids in goat milk are known to:

- be anti-bacterial,

- be antiviral,

- inhibit development and dissolve cholesterol deposits, and

- be absorbed rapidly from the intestine (SHINGFIELD et al., 2008)

Thus, these characteristics undoubtedly contribute to the specific health promoting properties of goat milk (SILANIKOVE et al., 2010).

When analysing the characteristics of goat milk, JANDAL (1996) reports on its several aspects:

Physicochemical aspects: Goat and sheep milk is white in colour compared with cow milk, which is yellowish because of the presence of carotene. Goat milk has a stronger flavour than sheep milk, and is alkaline in nature, which is very useful for people with stomach acid problems. This alkalinity is due to the higher protein content and a different arrangement of phosphates.

Medical aspects: Goat milk is prescribed by many doctors for children who are sensitive to cow milk, and is an alternative for people who are allergic to cow milk. Goat milk is very useful for people suffering from problems such as acidity, eczema, asthma, migraine, colitis, stomach ulcer, digestive disorder, liver and gallbladder diseases and stress-related symptoms, such as insomnia, constipation and neurotic indigestion.

Nutrition aspects: The fat of goat milk is more digestible than milk, and the fat molecules are smaller and have a greater surface area. Lipases in the gut are supposedly able to attack the lipids more rapidly. The proteins in goat milk are digested more readily and their constituent amino acids absorbed more efficiently than those of cow milk. Goat milk is recognised for its superior nutritional quality.

Biological aspects: Goat milk is easier to digest because of its natural homogenization, which is superior to the mechanical homogenization of cow milk. It takes approximately $20 \%$ less time to digest goat milk.

Immunological aspects: The non-allergenic properties of goat milk are due to the fact that most of the milk proteins are unable to pass through the walls of the digestive tract in their original, undigested, allergenic states.

The medicinal value of goat milk has been documented in Nepalese Ayurveda (Nepalese Traditional Medicine), Indian Ayurveda and goat milk was recommended as an affective dietary item for patients suffering from tuberculosis, dysentery, cough and cold and certain gynaecological disorders (BAJRACHARYA et al., 2010 and PAL et al., 2011 in BHATTARAI, 2012). 
MOWLEM (2005) examines the goat milk market of the UK in his study. He found that, in spite of the poor reputation of goat milk, the benefit of goat milk as a replacement of cow milk, when the latter has caused medical problems such as infantile eczema, has long been recognised. Many hospitals and medical practitioners kept a list of sources of goat milk that they could recommend to patients. The term 'universal foster mother' was often used to describe the goat. He emphasises that the UK is a strong milk drinking culture. It is vis-a-vis this milk drinking culture that they consider two main markets for goat milk and goat milk products in the UK: the 'health market' and the 'specialty food market'. The 'health market' is created by the demand for goat milk as an alternative to cow milk for people with a health problem and when goat milk is believed to be beneficial. He tells that one of the first scientific reports to suggest that goat milk may have health benefits was in the South African Medical Journal in 1956 (he refers to WALKER, 1956), when it was shown that a child with infantile eczema recovered when its diet was changed to include goat milk instead of cow milk. Walker had already written on the subject 8 years earlier in a paper titled "Goat's Milk as a Therapeutic Agent" (WALKER, 1948 in MOWLEM, 2005). Goat dairy products as specialty food products are to be found in many countries, including the UK. Cream and butter manufactured from goat milk are almost entirely consumed by those seeking to avoid cow dairy products on for health reasons. Both markets (health and specialty food) do not seem to be price sensitive. People buying goat products for health reasons are unlikely to worry too much about the cost, particularly if they can see some benefit from the consumption of these products. The speciality food market is also not particularly influenced by price. It can be seen as a luxury market where products are bought by those who can afford to buy out of interest rather than necessity. In the case of goat products, the higher profile these now receive in the press has done much to generate interest. Most newspapers have a food section, particularly in the coloured magazine supplements, and many of these have a regular recipe and menu section. There are very few weeks when goat products, particularly cheeses, do not get a mention. This encourages people to try these products and to include them when e.g. entertaining friends with dinner parties. To some, existing goat products have become 'trendy' (MOWLEM, 2005).

Goat milk and manufactured goat milk products have a three-fold significance in human nutrition, as HAENLEIN (2004) summarises:

- feeding more starving and malnourished people in the developing world than from cow milk;

- treating people afflicted with cow milk allergies and gastrointestinal disorders, which is a significant segment in many populations of developed countries;

- meeting the gastronomic needs of connoisseur consumers, which is a growing market share in many developed countries.

\section{The nutritional and medicinal importance of goat milk products}

GARCÍA et al. (2014) points out that the scientific quality of research on goat milk products is patchy, but is continuously improving.

In the last decade, there has been an increased interest in goat milk production and its conversion to value added products as well as a renewed interest in goat milk as an alternative milk source for people with cow milk intolerance (TZIBOULA-CLARKE, 2003; ALBENZO et al., 2006).

Goat milk products are considered to be the dairy products with the greatest marketing potential. Fermented goat milk incorporating live probiotic cells represents a group of products with great prospects in the future with regards to their nutritive and therapeutic properties (ZENEBE et al., 2014).

The chemical characteristics of goat milk can be used to manufacture a wide variety of products, including fluid beverage products (low fat, fortified, or flavoured) and UHT (ultra-high temperature) milk; fermented products, such as cheese, buttermilk or yogurt; frozen products, such as ice cream or frozen yogurt; butter; condensed/ dried products; sweets and candies (RIBEIRO and RIBEIRO, 2010; YANGILAR, 2013; PAL et al., 2017). Figure 5 shows the conversion of goat milk into main dairy products.

Figure 5: Conversion of milk into dairy products

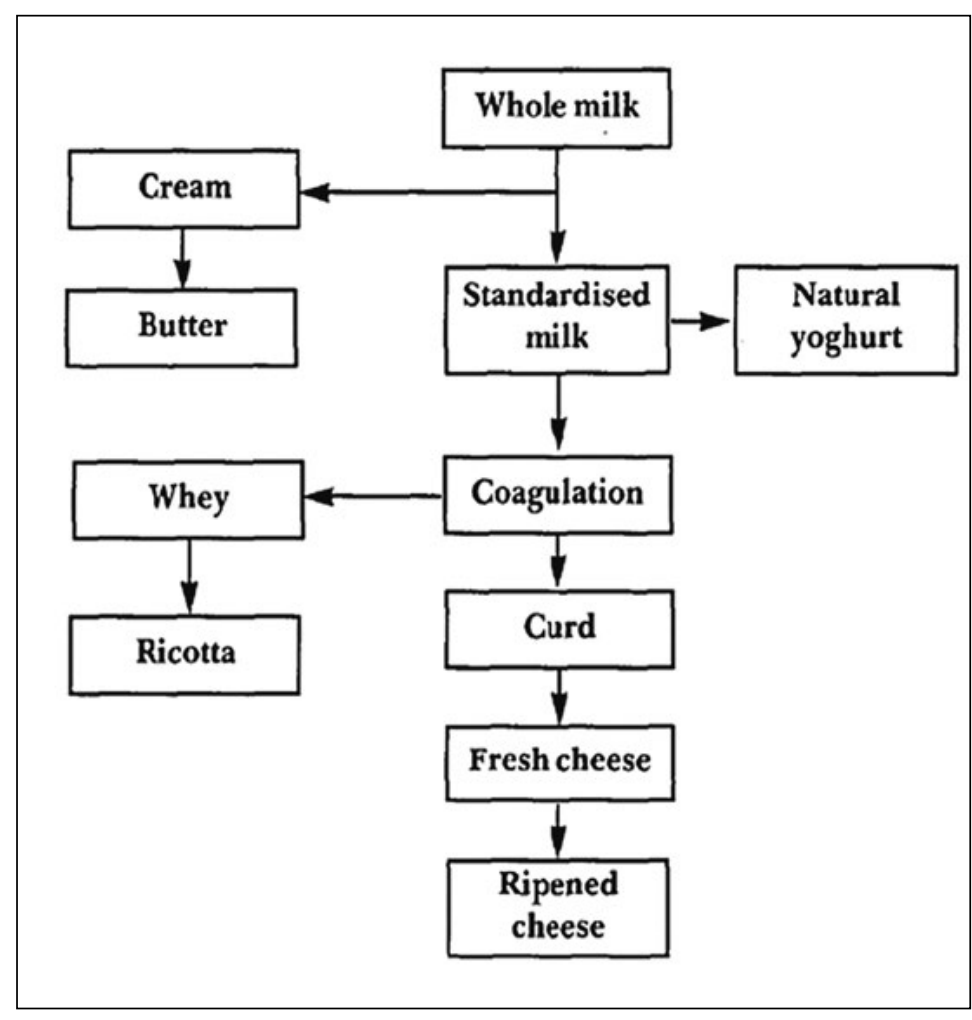

Source: Peacock, 1996 


\subsection{Nutritional value of manufactured goat dairy products}

\section{CHEESE}

Cheese is a fermented dairy product, which has hundreds of varieties. It is probably the most popular and well known value added dairy product (PAL, 2014 in PAL et al., 2017). The high fat-content of goat's milk makes it very suitable for cheese-making, and some delicious cheeses can be made (PEACOCK, 1996).

Chesses hold the greatest economic value among all manufactured goat milk products. Agricultural Handbook No. 54 of the USDA describes over 400 varieties of goat cheese and lists over 800 names of cheeses, many of which are made from goat milk or combinations of goat with cow, ewe, or buffalo milk (PARK, 1990 and SANDERS, 1969 in PARK, 2010).

Cheese may have been one of the first manufactured foods consumed by humans. History records its usage more than 4,000 years ago, but no one really knows when the first goat milk was made into cheese (LOEWENSTEIN et al., 1980). Goat milk, and the cheese made from it, was venerated in ancient Egypt, with some Pharaohs supposedly placing these foods among the other treasures in their burial tombs (SMITH, 2006). As far as we know, goat cheese originated in Mesopotamia. The milk was probably made into soft cheese, and then hard, ripened goat cheeses were later developed in the Mediterranean basin countries (PARK, 2001). The production of cheese from goats' milk has a very long history and is an important source of protein for people in several countries (KALANTZOPOULOS, 1993; SEIFU et al., 2004; YANGILAR, 2013).

There are goat cheeses made from raw and pasteurized milk. In many countries, the manufacture of goat cheese from raw milk is prohibited due to food safety issues (e.g. brucellosis). The type of milk used significantly influences the finished cheese (LOEWENSTEIN et al., 1980).

Hundreds of types of cheese are made around the world. Northern and Southern European countries have developed many types of goat's milk cheese, and the recipes for some have spread outside Europe. Few countries in the tropics traditionally make cheese, and even fewer make cheese from goat's milk. This reflects local traditions and the small quantities of milk produced by most goats in the tropics, rather than any lack of potential. India and Central and South America are the main areas in which goat's cheeses are produced. About 7.5 litres of milk are needed to produce one kilo of fresh cheese, but over 10 litres are needed to make a kilo of hard cheese. The harder cheeses often become popular with urban residents as they become richer and are able to afford them. It is good for poorer farmers to take advantage of the increase in wealth of urban dwellers and sell them valuable products, provided that the farmers get a fair price for their products (PEACOCK, 1996).

Main goat cheese types can be classified as follows: fresh and soft cheese; blue-veined cheese; semi-hard cheese; hard cheese (LIMA et al., 2018). In European countries, goat cheeses are marketed as premium cheese. Greece and France are the most important goat milk cheese producing countries in Europe. In India, goat milk has been used for making hard cheese. Goat cheese is easier on the human digestive system and lower in calories, cholesterol and fat than its bovine counterpart. Goat milk cheese is rich in calcium, protein, vitamin $\mathrm{A}$, vitamin $\mathrm{K}$, phosphorus, niacin and thiamin (ANON, 2012 in BHATTARAI, 2012).

In developed countries, sheep and goat cheeses are very well recognised by connoisseurs as gastronomic and festive products (RIBEIRO and RIBEIRO, 2010; MORAND-FEHR, et al., 2007).

\section{Yoghurt and other fermented milk products}

Yoghurt is made when milk is soured by certain selected bacteria, and not by other bacteria (PEACOCK, 1996). Currently, yoghurt is growing in popularity throughout the world, as people are now become aware of health benefits of probiotics in yoghurt. It is a fermented milk product that can be prepared with milk, cream, and skim milk. It is proven that fermented goat milk products are ideal food for people allergic to cow's milk. Goat milk is naturally homogenized. Its consumption helps improve slow digestion and absorption. Regular consumption of goat milk significantly improves weight and skeleton mineralization and also increases the level of vitamins, minerals and haemoglobin in blood serum. All these traits are significant advantage compared to human milk. Many studies have been conducted on fermented goat milk types. Goat milk yogurt is an excellent source of fatty acids, protein, and minerals; however, it is not well accepted by many consumers, due to its typical flavour (PAL, 2014 and PACINOVSKI et al., 2015 in PAL et al., 2017).

Kefir is a viscous, refreshing drink, with high acidity and varying amounts of alcohol and carbon dioxide. Health benefits of kefir were stated by FARNWORTH (2005), including stimulation of the immune system, inhibition of tumour growth, antimicrobial properties, gastrointestinal tract benefits and positive effects on cholesterol metabolism. Many traditional fermented goat milk types are made in developing countries (RIBEIRO and RIBEIRO, 2010).

\section{MILK POWDER}

Milk powder is prepared by removing the water from liquid milk. Milk powder has better keeping quality, requires less storage space and involves low transport cost (Pal, 2014 in PAL et al., 2017).

\section{DESSERTS AND SWEETS}

Ice cream made from goat milk is an attractive alternative for children and other consumers, due to its nutritional and antiallergenic properties and creamy organoleptic properties. Ice cream and frozen yogurt manufactured from goat milk are usually flavoured. Vanilla, chocolate, and premium white chocolate mix are the most commonly used flavours (PARK, 2010). KONAR and AKIN (1997) and PANDYA 
and GHODKE (2007) compared the chemical, physical and organoleptic qualities of ice cream made from cow, goat and sheep milk for their suitability for ice cream production. Goat milk proved to be the most acceptable ice cream followed by cow milk. CORREIA et al., 2008 in RIBEIRO and RIBEIRO, 2010 agreed and added that goat milk ice cream has a softer texture and specific melting characteristics.

'Cajeta' is a Mexican goat milk candy. It is a rich caramel sauce made from goat milk. Some Brazilian producers make goat milk 'Rapadura', mixing goat milk and sugarcane. It can include peanuts, coconut or chocolate. Chocolate goat milk can be produced, including organic chocolate goat milk in some countries. Cookies can also be made from goat milk. Each region has some typical cookies made from cow milk adapted to use goat milk. In Brazil, we can find 'Beliscăo' and 'Sequilhos' (RIBEIRO and RIBEIRO, 2010).

\section{BUTTER LIKE PRODUCTS}

Cream is produced by mechanical agitation of the whole milk to separate the fat globules. The fat globules are aggregated to form a semi-solid mass with $80-85 \%$ fat, transforming into butter. Cream and butter are manufactured from goat milk, but are almost entirely consumed by those seeking to avoid cow dairy products for health reasons (MOWLEM, 2005 in RIBEIRO and RIBEIRO, 2010). The production of butter from goat milk is not very common. It is artificially coloured sometimes in order to look similar to cow butter (LIMA et al., 2018).

\section{WHEY PRODUCTS}

MICHAELIDOU (2008) emphasizes that the coproduct of cheese manufacture, whey, is currently being viewed as a valuable source of bioactive components. Goat milk whey has higher levels of alpha lactalbumin, but is often discarded, or given to animals as a nutritional supplement, and little information on it is available. However, presently there are many products made from whey goat milk, among them are whey goat milk flavoured beverage, tablets, whey protein concentrate, and athletic supplements (PANDYA and GHODKE, 2007 in RIBEIRO and RIBEIRO, 2010).

As regards the marketing goat milk products, there are two formidable barriers :

- negative public perception of goaty flavour,

- seasonal milk production, which prevents yeararound uniform marketing.

To overcome these problems and achieve a sustainable dairy goat industry, effective strategies have to be sought (PARK, 2010).

The flavour goat milk is more intense in comparison to cow milk, which can restrict the acceptance of its derivatives by consumers (PARK and DRAKE, 2005; RIBEIRO and RIBEIRO, 2010; GOMES et al., 2013). While the typical goat taste is considered as a quality component in certain goat cheese products, for other products, the absence of characterising flavour is favourable (MORGAN and GABORIT, 2001; RIBEIRO and RIBEIRO, 2010; YANGILAR, 2013).

\section{CONCLUSIONS, SUMMARY}

Over the coming decades, the world will face important challenges related to environmental problems, global warming and human population growth. More people have to be fed with less external $\mathrm{CO} 2$ or NH4 emission. Animal husbandry is said to be the human activity most responsible for high gas emission and deforestation. Meanwhile, within the next 50 years, milk and meat production should be doubled. Goats are expected to play an important role in the future of milk production worldwide.

Furthermore, the demand for goat milk due to

- special health conditions,

- the growth in lifestyle markets, ethical, fair trade and sustainable products,

- eco/agro-tourism, new environmental and biodiversity markets,

- the growing market share of connoisseur consumers is expected to grow continuously.

\section{REFERENCES}

Albenzo, M., Caroprese, M., Marino, R., Muscio, A., Santillo, A., Sevi, A. (2006): Characteristics of Garganica goat milk and Cacioricotta cheese. Small Ruminant Research (64): 35-44

Anaeto, M., Adeyeye, J. A., Chioma, G. O., Olarinmoye, A. O., Tayo, G. O. (2010): Goat products: Meeting the challenges of human health and nutrition. Agriculture and Biology Journal of North America. 1(6): 1231-1236

Baldo, B. A. (1984): Milk allergies. Australian Journal of Dairy Technology 39:120-128

Barna, M (2009): A kiskérôdzők tejének szerepe a gyermekek táplálkozásában. In: A tej szerepe a humán táplálkozásban (Szerk.: Kukovics, S), Melánia Kiadó, Budapest, 453-464

Bhattarai, R. R. (2012): Importance of goat milk. Journal of Food Science and Technology Nepal. (7) 107-111

Billion, P. (2003): Milking management. In: Roginski, H., Fuquay, J. W., Fox, P. F. (Eds.), Encyclopaedia of Dairy Sciences. Academic Press, Cornwall, 1243-1253

Csapó, Zs., Csapóné R. T. (2019): Kecsketartás, kecsketejtermelés, kecsketej-termékek jelentősége, fogyasztása regionális kitekintéssel. Régiókutatás Szemle. 2019 (1). DOI: 10.30716/ RSZ/2019/1/9. 97-109.

Darcan, N. K., Silanikove, N. (2018): The advantages of goats for future adaptation to Climate Change: A conceptual overview. Small Ruminants Research 163 34-38

Devendra, C. (1999): Goats: challenges for increased productivity and improved livelihoods. Outlook on Agriculture. 28: 215-226

Devendra, C. (2001): Small ruminants' imperatives for productivity enhancement, improved livelihoods and rural growth - a review. Asian-Australasian Journal of Animal Science. 14(10): 1483-1496

Devendra, C., McLeroy, G. B. (1982): Goats and sheep reproduction in the tropics. ELBS edition. Longman. Singapore. pp. 78.

Domonkos, A., Greiner, E. (2009): A kiskérődzők teje a felnőttek 
táplálkozásában és a gyógy élelmezésben. In: A tej szerepe a humán táplálkozásban (Szerk.: Kukovics, S), Melánia Kiadó, Budapest, 465-481

Dubeuf, J. P. (2010): Characteristics and diversity of the dairy goat production systems and industry around the world. Structural, market and organisational conditions for their development. Tecnol. Ciênc. Agric., 4 (2010), pp. 25-31

Dubeuf, J. P., Morand-Fehr, P., Rubino, R. (2004): Situation, changes and future of goat industry around the world. Small Ruminant Research. 51:165-173

Farnworth, E.R. (2005): Kefir-A Complex Probiotic. Food Science \& Technology Bulletin: Functional Foods 13 May.

Fenyvessy, J. (2009): A kiskérődzők tejének értékes tulajdonságai a fogyasztás és a feldolgozás szempontjából. In: A tej szerepe a humán táplálkozásban (Szerk.: Kukovics, S), Melánia Kiadó, Budapest, 417-424

Fevrier, C., Mourot, J., Jaguelin, Y., Mounier, A., leberton, Y. (1993): Comparative digestive utilization of UHT goat and cow's milk: nutritional effects of galation-use of a swine model. Lait 73:581-592

García, V., Rovira, S., Boutoial, K., López, M. B. (2014): Improvements in goat milk quality: A review. Small Ruminant Research 121: 51-57

Gomes, J. J. L., Duarte, A. M., Batista, A. S. M., Figueiredo, R. M. F., Sousa, E. P., Souza, E. L., Queiroga, R. C. R. E. (2013): Physicochemical and sensory properties of fermented dairy beverages made with goat's milk, cow's milk and a mixture of the two milks. LWT - Food Science and Technology (54) 18-24

Guo, M., Park, Y. W., Dixon, P. H., Gilmore, J. A., Kindstedt, P. S. (2004): Relationship between the yield of cheese (Chevre) and chemical composition of goat milk. Small Ruminant Research (52) $103-107$

Haenlein, G. F. W., Caccese, R. (1984): Goat milk versus cow milk. In: Haenlein, G.F.W., Ace, D. (Eds.), Extension Goat Handbook. Fact Sheet E-1. United States Department of Agriculture, Washington, DC, 1984.

Haenlein, G. F. W. (2001): Past, present and future perspectives of small ruminant dairy research. Journal of Dairy Science 84(9): 2097-2445

Haenlein, G. F. W. (2004): Goat milk in human nutrition. Small Ruminants Research. 51: 154-163

Haenlein, G. F. W. (2017): Why does goat milk matter? - A Review. Nutrition \& Food Science International Journal 2(4): DOI: 10.19080/NFSIJ.2017.02.555594

Harren, R. V. (1994): The science of animal agriculture. Delmar Publisher Inc. Albany, New York. 122212

Host, A., Husby, S., Osterballe, O. (1988): A prospective study of cow's milk allergy in exclusively breast-fed infants. Acta Paediatrica Scandinavica 77:663-670

Hungarian Chamber of Agriculture (2017): A kiskérôdző ágazat stratégiai fejlesztése 2015. In: A kiskérôdzô szektor jelene és jövője - A Juh Terméktanács 25 éve tükrében. (Szerk: Kukovics, S) $159-172$

Idachaba, F. S. (2000): Desirable and Workable Agricultural Policies for Nigeria. Ibadan University Press. pp 3-9

Jandal, J. M. (1996): Comparative aspects of goat and sheep milk. Small Ruminant Research 22: 177-185
Jenness, R. (1980): Composition and characteristics of goat milkReview. Journal of Dairy Science. 63: 1605-1630

Kalantzopoulos, G. C. (1993): Cheese from ewes' and goats' milk. In P. F. Fox (Ed.), Cheese: Chemistry, physics and microbiology, Vol. 2. Major cheese groups (2nd edition), London: Chapman \& Hall, 507-553.

Kocsiné Gráf, M. (2011): A szánentáli kecskék életkorának és kondíciójának hatása a tejtermelésre és a szaporaságra. PhD Thesis. Debreceni Egyetem Agrár- és Gazdálkodástudományok Centruma, Állattenyésztési Tudományok Doktori Iskola

Konar, A., Akin, S. (1997): Comparative study of the chemical, physical and organoleptic qualities of ice cream made from cow, goat and ewe milk. Doga Turk Tarim Ormancilik Dergisi 16, 711-720.

Kris, H. K. (2008): The history of domestication of goats. Journal of Archaeological Science (28) 61-79

Kukovics, S. (2007a): A kecsketartásban alkalmazott gyephasználat. Magyar Mezőgazdaság, Magyar Juhászat + Kecsketenyésztés 16(3) 4-7

Kukovics, S. (2007b): Az anyakecske tartás támogatása. Őstermelô: Gazdálkodók Lapja 11(4):92

Kukovics, S. (2008a): A Magyar juh- és kecskeágazat helyzete és kilátásai. Magyar Mezôgazdaság. Magyar Juhászat + Kecsketenyésztés 17(3):2-8

Kukovics, S. (2008b): Létszám és termelésváltozások az Európai (EU), valamint a magyar juh és kecskeszektorban. In: "A juhtenyésztés jelene és jövője az EU-ban"; (szerk.: Kukovics, S. - Jávor, A.); ISBN 978-963-8030-58-0. Kiadó: Magyar Juhtejgazdasági Egyesület - Debreceni Egyetem Agrárés Múszaki Tudományok Centruma Herceghalom - Debrecen, 2008. 9-29

Kukovics, S. (2008c): Az EU juh- és kecskeágazata helyzetének felülvizsgálata. Magyar Mezőgazdaság. Magyar Juhászat + Kecsketenyésztés 17(6):2-3

Kukovics, S., Baranyai G. (2016): Goat breeds and breeding programmes in Hungary. 43-50. In: Sustainable Goat Breeding and Goat Farming an Central and Eastern European Countries. European Regional Conference on Goats 7-13 April 2014 Ed.: Kukovics, S. ISBN 978-92-5-109123-4

Lima, M. J. R., Teixeira-Lemos E., Oliveira, J., Teixeira-Lemos L. P., Monteiro, A. M. C., Costa, J. M. (2018): Nutritional and Health Profile of Goat Products: Focus on Health Benefits of Goat Milk. 189-232. http://dx.doi.org/10.5772/intechopen.70321 In: Goat Science. Ed.: Kukovics, S. Print ISBN 978-1-78923202-8. Online ISBN 978-1-78923-203-5

Loewenstein, M., Speck, S.J., Barnhart, H.M. (1980): Research on goat milk products: a review. Journal of Dairy Science (63) $1631-1648$

López-Aliaga, I., Alférez, M. J. M., Barrionuevo, M. J., Nestares, T., Sanz-Sampelayo, M. R., Campos, M. S. (2003): Study of nutritive utilization of protein and magnesium in rats with resection of the distal small intestine. Beneficial effect of goat milk. Journal of Dairy Science (86) 2958-2966.

Marticsek, J., Előd, R., Székelyhidi, T.,Pataki, R., Belényesi, M. (1999): A kecskeágazat szerepe a nemzeti vidékfejlesztési és környezetgazdálkodási programokban. VI. Debreceni Állattenyésztési Napok. Debrecen. 100-109

Michaelidou, A. M. (2008): Factors influencing nutritional and health profile of milk and milk products. Small Ruminant 
Research (79) 42-50

Morand-Fehr, P (2003): Strategy for goat farming in the 21st century. Small Ruminant Research 51(2): 175-183

Morand-Fehr, P., Boyazogly, J. (1999): Present status and future outlook of the small ruminant sector. Small Ruminant Research 34:259-269

Morand-Fehr, P., Fedele, V., Decandia, M., Le Frileux, Y: (2007) Influence of farming and feeding systems on composition and quality of goat and sheep milk. Small Ruminant Research 68:20-34

Morgan, F., Gaborit, P. (2001): The typical flavour of goat milk products: technological aspects. International Journal of Dairy Technology 54(1) 38-40

Mowlem, A. (2005): Marketing goat dairy produce in the UK. Small Ruminant Research 60:207-2013

Olalla, M., Ruiz-López, M. D., Navarro, M., Artacho, R., Cabrera, C., Gimènez, R., Rodriquez, C., Mingorance, R. (2009): Nitrogen fractions of Andalusian goat milk compared to similar types of commercial milk. Food Chemistry (113) 835-838

Pal, M., Dudhrejiya, T. P., Pinto, S. (2017): Goat milk products and their significance. Beverage \& Food World. 44(7) 21-25

Pandya, A.J., Ghodke, K.M. (2007): Goat and sheep milk products other than cheeses and yoghurt. Small Ruminant Research (68) 193-206

Park, Y. W. (1994): Hypo-allergenic and therapeutic significance of goat milk. Small Ruminant Research 14: 151-161

Park, Y.W. (2001): Proteolysis and lipolysis of goat milk cheese. Journal of Dairy Science (84-E. Suppl.), E84-E92.

Park, Y. W. (2010): Goat milk products: Quality, composition, processing, and marketing. In: Encyclopaedia of Animal Science, Publisher: CRC Press, Editors: Pond, W. G. and N. Bell, N.

Park, Y. W. (2011): Proteolysis and lipolysis of goat milk cheese. Journal of Dairy Science, 84 (E. Suppl.), E84-E92.

Park, Y. W., Chukwu, H. I. (1989): Trace mineral concentrations in goat milk from French-Alpine and Anglo-Nubian breeds during the first 5 months of lactation. Journal of Food Composition and Analysis 2: 161-169

Park, Y. W., Drake, M. A. (2005): Effect of 3 months frozenstorage on organic acid contents and sensory properties, and their correlations in soft goat milk cheese. Small Ruminant Research (58) 291-298.

Peacock, C. (1996): Improving Goat Production in the Tropics. Oxfam/FARM-Africa, 307-315

Peacock, C. (2008): Dairy goat development in East Africa: a replicable model for smallholders? Small Ruminants Research 77(2): 225-238

Peacock, C., Sherman, D. M. (2010): Sustainable goat production - Some global perspectives. Small Ruminants Research 89. 70-80

Pirisi, A., Lauret, A., Dubeuf, J. P. (2007): Basic and incentive payments for goat and sheep milk in relation to quality. Small Ruminant Research (68) 167-178

Polgár, M (2009): Van-e alternatív tejtáplálás a tehéntej-allergiás csecsemôk és gyermekek számára? In: A tej szerepe a humán táplálkozásban (Szerk.: Kukovics, S), Melánia Kiadó, Budapest, 437-443

Ramos Morales, E., De la Torre Adarve, G., Carmona López, F. D., Gil Extremera, F., Sanz Sampelayo, M. R., Boza, J.
(2005): Nutritional value of goat and cow milk protein. Options Méditerranéennes (67) 167-170

Ribeiro, A. C., Ribeiro, S. D. A. (2010): Specialty products made from goat milk. Small Ruminant Research (89) 225-233

Seregi, J., Kovács Á. (2016): Data on the importance of goat milk and meat in human nutrition. 195-201. In: Sustainable Goat Breeding and Goat Farming an Central and Eastern European Countries. European Regional Conference on Goats 7-13 April 2014 Ed.: Kukovics, S. ISBN 978-92-5-109123-4

Seifu, E., Buys, E. M., Donkin, E. F. (2004): Quality aspects of Gouda cheese made from goat milk preserved by the lactoperoxidase system. International Dairy Journal (14) 581-589

Shingfield, K.J., Chilliard, Y., Toivonen, V., Kairenius, P., Givens, D.I. (2008): Trans fatty acids and bioactive lipids in milk. Adv. Exp. Med. Biol. 606: 3-65.

Silanikove, N. (1994): The struggle to maintain hydration and osmoregulation in animals experiencing severe dehydration and rapid rehydration: the story of ruminants. Exp. Physiol. 79, 281-300.

Silanikove, N. (2000): The physiological basis of adaptation in goats to harsh environments. Small Ruminant Research (35) 181-193

Silanikove, N., Darcan, N. K. (2015): Impact of climate change on the dairy industry in temperate zones: Predications on the overall negative impact and on the positive role of dairy goats in adaptation to earth warming. Small Ruminants Research 123: 27-34

Silanikove, N., Leitner, G., Merin, U., Prosser, C. G. (2010): Recent advances in exploiting goat's milk: Quality, safety and production aspects. Small Ruminant Research (89) 110-124

Smith, V. (2006): Food fit for the soul of a Pharaoh. The Mortuary temple's bakeries and breweries. Expedition 48 (2): 27-30

Steinfeld, H., Gerber, P., Wassenaar, T., Castel, V., Rosales, M., de Haan, C. (2006): Livestock's Long Shadow: Environmental Issues and Options. Food and Agriculture Organization of the United Nations, 82-114.

Szigeti, O. (2004): Kecsketejből készült élelmiszerek táplálkozási előnyei és fogyasztói szokásai. Élelmiszer, Táplálkozás és Marketing. 1 (1-2) 1-17

Szigeti, O., Szente, V., Szakály, Z. (2005): Fogyasztói megítélés a kecsketej termékek piacán. Élelmiszer, Táplálkozás és Marketing. 2 (1-2) 29-37

Szigeti, O., Szente, V., Szű́cs, A., Szendrő, K. (2014): Kecsketej termékek fogyasztói megítélése. Élelmiszer, Táplálkozás és Marketing. 10 (2) 29-34

Taitz, L. S., Armitage, B. L. (1984): Goat's milk for infants and children. Br. Med. J., (288) 428-429

Thornton, P. K. (2010): Livestock production: Recent trends and future prospects. Philosophical Transactions of the Royal Society of London. Series B, Biological Sciences. 365(1554): 2853-2867

Tziboula-Clarke, A. (2003): Goat milk. In: Roginski, H., Fuquay, J.W., Fox, P.F. (Eds.), Encyclopedia of Dairy Sciences. Academic Press, Cornwall, 1270-1279

Yangilar, F. (2013): As a potentially functional food: Goat's milk and products. Journal of Food and Nutrition Research 1(4): 68-81 Zeman, F. J. (1982): Clinical nutrition and dietetics. Callamore 
Press, D. C. Health \& Co. Lexington, Massachusetts. USA

Zenebe, T., Ahmed, N., Kabeta, T., Kebede, G. (2014): Review on Medicinal and Nutritional Values of Goat Milk. Academic Journal of Nutrition 3 (3): 30-39

Department of Agriculture, Forestry and Fisheries, Republic of South Africa (2016): https://www.nda.agric.za/doaDev/sideMenu/ AgroProcessingSupport/docs/Goat\%20Milk\%20document $\% 20$ final.pdf

Eurostat (2017): https://ec.europa.eu/eurostat/statistics-explained/ index.php/Agricultural_production_-_animals\#Livestock_ population

FAO (2018): http://www.fao.org/dairy-production-products/ production/dairy-animals/small-ruminants/en/

KSH (2018a): http://www.ksh.hu/docs/hun/agrar/html/ tabl1_5_1_2.html

KSH (2018b): http://www.ksh.hu/docs/hun/agrar/html/ tabl1_5_3_4.htm

UN (2017): https://esa.un.org/unpd/wpp/publications/files/ wpp2017_keyfindings.pdf

worldatlas (2017): https://www.worldatlas.com/articles/the-topgoat-milk-producing-countries-in-the-world.html 